Facultatea de Litere, Universitatea Bucureşti

\title{
DESPRE EDUCAȚIE, LIBERTATE ȘI DECENȚĂ INN FOLOSIREA ȘI CULTIVAREA LIMBII ${ }^{3}$
}

Convingerea mea este aceea că cercetarea științifică, în mod particular cea din domeniul umanist, trebuie să promoveze un spirit deschis, dubitativ și nuanțat, fără să apeleze la soluții extreme, cu răspunsuri categorice, în alb și negru. Lingvistica și literatura, istoria și filozofia, teologia și artele pun singure întrebări despre crearea și condiția omului, despre evoluția acestuia și a societății din care face parte, asupra valorilor fundamental umane și a schimbărilor de optică și de mentalitate legate de acestea, asupra trecutului și a viitorului etc. și încearcă să dea răspunsuri cât mai potrivite în funcție de criterii cronologice, geografice, socio-istorice și culturale, plecând de la principiul că ceea ce pare a fi valabil dintr-un punct de vedere nu este, în mod obligatoriu, valabil din alt sau alte puncte de vedere. Ca oameni de carte, putem avea convingeri și ezitări, primele bazate pe argumente, celelalte pe principiul - de multe ori validat practic - că o teorie categorică poate fi combătută și, în ultimă instanță, înlocuită cu o alta, rezultată în urma unor cercetări diverse sau suplimentare.

Știinţă interdisciplinară având ca obiect de studiu limba unui vorbitor, a unei comunitătii (în primul rând geografice sau socioprofesionale), a unui popor sau grup de popoare, văzută în evoluția și funcționarea ei, lingvistica "tradițională" presupune nu de puține ori interpretări multiple, oscilând între postulate teoretice generale, legi de evoluție istorică dublate de notabile excepții, reguli de funcționare valabile în perioade și contexte determinate, soluții convenționale și cu valabilitate discutabilă în sensul denotativ al cuvântului. Astăzi nu vom aduce în discuție decât implicit evoluția istorică a limbii și vom insista, în mod particular, asupra relației dintre vorbitorii nativi și limba moștenită de la părinți, structurată, îmbogățită și rafinată prin educație și, ca urmare, prin integrarea în mediul socioprofesional dorit.

3 Lucrarea a fost susținută în plenul conferinței Lexic comun / Lexic specializat. Limba și cultura română în context național și european: evaluări și perspective la Centenarul Unirii, Galați, 26-27 octombrie 2018. 
Limba pe care o vorbim astăzi sau pe care o auzim vorbindu-se în jurul nostru reprezintă, așadar, rezultatul unor succesiuni de etape "familiale" (i.e. realizate în mediul restrâns și inițial al familiei), educaționale (din punct de vedere instituțional) și autoeducaționale, cea din urmă influențată, desigur, de mediile familial, școlar, social și profesional în care creștem, suntem instruiți, trăim și ne desfăşurăm activitatea și viața în general. Se știe că, dincolo de existența „limbii istorice” - teoretizată ca atare de către Eugeniu Coșeriu -, într-o societate există și se manifestă multiple "limbi funcționale", diferite în funcție de variatele domenii de activitate, de gradul de educație a vorbitorilor, de presiunea lingvistică a mediului sau, dimpotrivă, de asumarea - arogantă sau constructivă - a unor intenții auctoriale manifestate asupra actului comunicativ. Cei mai mulți dintre vorbitorii instruiți sau în curs de educare au, mai mult sau mai puțin voit, o anumită poziționare asupra limbii pe care o folosesc, de la reflecția permanentă asupra ei până la indiferență, de la temerea naturală că nu este bine până la disprețul afișat că nu este suficient, de la conservatorism la maximă libertate de exprimare, în sfârșit, de la limbajul de lemn până la cel care atinge limitele - e adevărat, variabile - ale suportabilului. În acest context, limba literară standard despre care învățăm la școală devine din ce în ce mai mult o abstracțiune, iar normele care o guvernează în mod convențional nu mai țin pasul, în mod obiectiv, cu variațiile calitative și cantitative ale actualei etape de evoluție, caracterizată, pe de o parte, de inovații preponderent analogice și, pe de altă parte, de integrare în fluxul șablonard al globalizării lingvistice.

Cum se poate interpreta sau cum se poate face față unei asemenea stări de fapt este o întrebare frecventă atât a „responsabililor” cu soarta limbii, cât și a unui public nespecialist destul de larg și vizibil în media românească. Cei dintâi ezită în acceptarea inovațiilor lingvistice apelând la criterii discutabile, iar faptul că nu există încă, la nivel academic, o preocupare constantă și cuprinzătoare de gestionare a intrărilor în limbă nu este un lucru de laudă... Există, fără îndoială, destule și cunoscute dicționare de neologisme, generale sau specializate, inclusiv de cuvinte recente, apărute în ediții succesive, care fie preiau cuvinte din alte limbi, fie atestă lexicografic apariții lexicale și frazeologice preluate din presa actuală, dovada cea mai vizibilă a inovațiilor în limbă. Pătrunderea cuvintelor noi este o realitate care nu poate și nu trebuie combătută, iar folosirea lor într-o formă sau alta (din necesitate funcțională sau din snobism, cu măsură sau, dimpotrivă, peste măsură) cere, totuși, înainte de toate, cunoașterea regulilor de scriere și de pronunțare din limba sau limbile-surse și, în egală măsură, cunoașterea mecanismelor structurale ale propriei limbi, care să 
faciliteze o anumită încadrare, respectiv funcționare morfosintactică și care să indice măsura posibilității sau posibilităților de românizare. Din acest punct de vedere, cuvintele-cheie sunt educația, spiritul limbii și măsura, prin care vorbitorii - cel puțin mediu instruiți - decid să-și varieze sau, dimpotrivă, să-și schematizeze limbajul, să se exprime nuanțat sau în una dintre modalitățile de realizare a limbajului de lemn, să își modeleze exprimarea în funcție de context, să se reprezinte prin limba pe care o folosesc asumându-și, prin asta, apartenența la un anumit statut intelectual și social. Atât neologismele propriu-zise, cât, mai ales, inovațiile lexicale și frazeologice recente, externe, interne sau mixte merită credit și interes din partea noastră atâta vreme cât sunt folosite conștient sau sunt conștientizate la timp, cât respectă tendințe firești ale limbii noastre (de economie, de expresivitate sau de hipercorectitudine) și cât se produc prin mecanisme analogice validate de tradiția lingvistică. În cazul lor, chiar dacă numai viitorul va decide dacă vor rămâne creații efemere sau dacă vor primi girul comunității, un efort din partea noastră către explicarea, contextualizarea și înțelegerea lor poate conduce - sunt convins de asta - la o îmbogățire echilibrată și la o diversificare a posibilităţilor de comunicare ale vorbitorilor limbii noastre. Acest efort reprezintă unul dintre aspectele respectului pe care îl putem avea faţă de propria noastră limbă prezentă, trecută și mai ales, viitoare.

Revenind la „normă”, reglementarea inovațiilor trebuie să aibă în vedere, după opinia noastră, următoarele caracteristici:

1. respectarea regulilor structurale ale limbii proprii;

2. respectarea - cel puțin ca posibilitate - a opțiunilor culturallingvistice ale vorbitorilor, atâta vreme cât și le asumă în cunoștință de cauză;

3. validarea socială și culturală a faptelor de limbă.

Vom lua pe rând principalele niveluri ale limbii și vom încerca să dăm exemple de situații în care un vorbitor se exprimă decent în propria limbă fără să trezească mirări sau reticență din partea celorlalți. Spre exemplu, dubla posibilitate de accentuare a unor cuvinte, în mod special din categoria neologismelor, nu trebuie respinsă de plano atâta vreme cât ea poate avea fie argumente etimologice indiscutabile, confirmate de evoluția istorică, fie, eventual, argumente analogice greu de respins, impuse prin uz. Variante accentuale de tipul anatémă și anátemă "excludere din sânul Bisericii sub acuzația de erezie; afurisenie" se explică prima din franceză

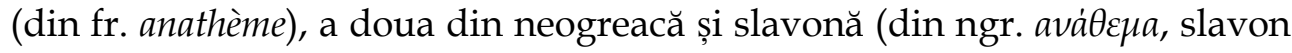
anafema, ana(f)tema, anathema); asfixie și asfixie sunt explicabile prima din fr. asphyxie, a doua din it. asfissia; alternanța áudit și audit „examinare 
profesională a unor informații cu scopul de a exprima o opinie responsabilă și independentă în raport cu un anumit standard" reproduce atât pronunțarea latinizată a engl. audit (cf. și it. audit), cât și corespondentul fr. audit; accentuarea dublă búldog și buldóg se explică, în egală măsură, prin engl. bull-dog și prin fr. bouledogue (la rândul său, adaptare a etimonului englezesc); variantele cólaps și coláps au aceeași dublă explicație, prima provenind din engl. collapse, iar a doua din lat. collapsus și din fr. collapse; coexistența accentuărilor gigoló/gígolo „bărbat tânăr întreținut de o femeie mai în vârstă decât el; tânăr elegant, dar cu moravuri dubioase" se explică atât printr-o origine franco-italiană, cât și prin una anglo-germană; pronunțarea gúlag „sistem concentraționar (la origine, sovietic)” se explică prin it. gúlag și/sau prin germ. Gúlag, în timp ce gulág are ca punct de reper rus. gulag/zyıaz și/sau fr. goulag; pronunțarea oxitonă internét pentru „rețea informatică mondială între computere conectate la diferite rețele locale" provine din fr. internet (susținută analogic de net), în timp ce pronunțarea internet (din ce în ce mai frecventă) se explică după cea anglo-americană, situație comparabilă cu dubletul Interpól (din fr. Interpol) și Ínterpol (după engl. Interpol); accentuarea módem („dispozitiv periferic în informatică”) reproduce pronunțarea engl. modem (cf. it. modem), în timp ce modém se explică prin fr. modem); variantele mánager „specialist în conducerea unei societăți, antreprize, companii etc., impresar" (din engl. manager) și manáger (accentuare paroxitonă explicabilă prin românizare) sunt prima etimologică și a doua, cel mai probabil, analogică, dar cel puțin la fel de întrebuințată, în aceeași situație cu dubletul accentual pénalty și penálti „lovitură de pedeapsă la fotbal, de la 11 metri de poartă", primul component etimologic (din engl. penalty), iar al doilea românizat tot prin accentuare paroxitonă; penúrie și penuríe („lipsă, sărăcie”) sunt împrumuturi, pe de o parte, din lat. penuria (cf. și it. penúria) și, pe de altă parte, din fr. pénurie; pónei („,rasă mică de cai...") are origine engleză (pony), iar varianta secundară ponéi are origine franceză (poney < engl. pony); la fel se explică și variantele accentuale substantivale lógo, pl. lógouri (din engl. logo) și logó, pl. logóuri (din fr. $\log o)$ „emblemă - simbolică și de identificare - a unei mărci comerciale, a unei firme, a unei societăți, a unei instituții etc.", minúție (din lat. minutia, cf. it. minuzia) și minuţíe (din fr. minutie) „meticulozitate, minuțiozitate", prognóstic (cf. it. prognóstico, lat. prognósticus, -a, germ. Prognóstik[um]) și prognostíc (din fr. pro(g)nostic) "prognoză medicală", protéctor (din lat. protector, -oris) și protectór (din fr. protecteur), satíră (din fr.

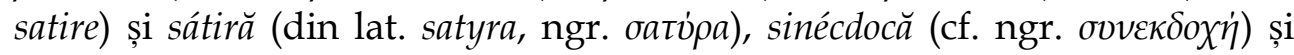
sinecdócă (din fr. synecdoque), tráfic (din it. traffico, cf. engl. traffic) și trafíc (din fr. trafic) etc. 
Accentuările cu suport etimologic ale variantelor menționate mai sus au putut fi sprijinite inclusiv de tendințe interne sau de diverse asocieri analogice, iar unele dintre ele (mai ales în cazul cuvintelor cu mare frecvență) tind să se specializeze semantic. Această realitate este confirmată de considerarea multora dintre ele de către DOOM în variație liberă. Legat de acest aspect al pronunțării, fonetice şi/sau accentuale, un anumit grad de decență lingvistică ar trebui să ne facă să acceptăm, mai ales în cazul numelor proprii sau al împrumuturilor recente insuficient adaptate, atât forma etimologică, cât și pe cea românizată, cea de a doua respectând, cu necesare și firești ajustări, identitatea dintre scriere și pronunțare. $\mathrm{Nu}$ este, așadar, nicio problemă particulară dacă auzim rostindu-se Florida atât românește, cât și, eventual, englezește, la fel Edinburgh, Hawaii, San Francisco etc. Putem oscila, ca vorbitori de limbă română, între accentuări analogice și etimologice ca Andalúzia și Andalucía/Andaluzía, Bósfor și Bosfór, Búdapesta și Budapésta, Kíev sau Kiév, Copenhága și Cópenhaga, Léningrad și Leningrád, Luxembúrg și Lúxemburg, Monáco și Monacó, Nicósia și Nicosía, Stálingrad și Stalingrád, Rúsia sau Rusía, Ucráina sau Ucraína etc., deși, ca recomandare generală, este de dorit adaptarea "tradițională" la specificul propriei limbi. Cunoașterea unei limbi străine sau simpla curiozitate intelectuală ne poate face să pronunțăm exclusiv Bogotá, Cádiz, Génova sau Génoa, Módena, Padova, Rio de Janeiro sau Rio de Janeiru etc., în ciuda unor eventuale tentații, populare sau hipercorecte. În cazul antroponimelor, rigiditatea normei este cu atât mai relativă cu cât o persoană are dreptul să își pronunțe numele, din varii motive, cum crede de cuviință: Anastasía, dar și Anastásia, Carageá sau Carágea, Claúdia sau Cláudia, Míron sau Mirón etc.; totuși, însă, o minimă decență ne îndreaptă să pronunțăm „ca la carte" Armánd, Baláci, Duíliu, Faragó, Harét, (Costache) Négri, Papahagí, Saligny etc., chiar dacă, măcar în cazul unora, uzul își cere pregnant drepturile (vezi, spre exemplu, cel puțin variantele Bálaci și Papahági). La fel, în domeniul economiei recente, sunt admisibile, după opinia noastră, pronunțări duble ca "Áudi" și „Aúdi", "BiEmVi” și „BeEmVe", "Fíat” și „Fiát”, ,Mércedes" și "Mercédes", ,Merțédes", „Maserati" și „Mazerati", „Opel" și „Opăl”, ,Porșă" și "Porșe", "Skoda" și "Škoda", "Suzúki" și "Suzukí,, "Fólkswagăn" și "Vólkswagăn" etc., nume comerciale care oscilează între pronunțarea originară și cea adaptată fiecărei limbi în care sunt ele folosite. Pe de altă parte, o expresie de tipul all inclusiv trebuie rostită integral englezește, nu cu accent oxiton, așa cum se aude nu de puține ori. La fel, numele unui cunoscut local bucureștean este „Trattoría Buongiorno", nu „trattória”, cum se pronunță fals à litalienne, în reclama aferentă... Sunt acestea cuvinte românești? Este puțin important... Ele sunt, însă, folosite în societatea 
românească actuală și cunosc adaptări similare cu cele ale cuvintelor limbii noastre. Faptul că le folosim impune să arătăm că le știm originea și istoria, fără să facem paradă de asta și fără să evităm, în același timp, integrarea lor în structurile interne ale propriei limbi. Aceasta se numește decență lingvistică.

Variația fonetică este o realitate care trebuie luată în mod obiectiv în considerare inclusiv în exprimarea curentă şi neologică. Astfel, sub presiunea modelelor analogice deja validate la nivel literar sau sub influența modelelor mai vechi, sunt admisibile în comunicarea orală dublete de tipul adulter și adulteriu, aleatoriu și aleator, angină și anghină, canion și ca-ni-on, cas-ta-nie-tă și cas-ta-ni-e-tă, coa-fa și co-a-fa, ma-chi-a și machia, ex-ploa-ta și ex-plo-a-ta, franciză și franșiză, mau-so-leu și ma-u-so-leu, miliéu și mi-leu [discutabil dubletul din $\mathrm{DOOM}^{2}$ pizza/pizză], ralanti și relanti(u), re-ve-li-on și re-ve-ion, so-vi-et și so-viet, sangvin și sanguin, ștecăr și ștecher, trau-mă și tra-u-mă etc., multe reprezentând tendințe firești și acceptabile ale limbii noastre. În toate aceste cazuri, norma literară actuală este unică și trebuie recomandată, în consecință, la nivel școlar, însă abaterile de la normă sunt suficient de frecvente și de argumentabile analogic pentru a nu fi considerate "greșeli" și pentru a nu fi date ca exemplu de "aşa nu" la diverse examene de admitere la facultate, spre exemplu, cel puțin la acele facultăţi care nu urmăresc exclusiv ce memorie are candidatul, ci și cum gândește și ce simț al limbii stăpânește. Pe de altă parte, eliminarea din principalul dicționar normativ al limbii actuale a lui picromigdală în favoarea exclusivă a variantei secundare interne pricomigdală nu este o soluție fericită cel puțin din trei motive: pe de o parte, varianta etimologică picromigdală este încă atestată în scris și, pe de altă parte, este trecută fie ca titlu unic (vezi DLR, DEX 98, NODEX 02, DEXI 07), fie, în intrare, ca variantă liberă (vezi MDN 00); în sfârșit, dacă un singur vorbitor o folosește în cunoștință de cauză, ea are dreptul să fie notată măcar ca variantă secundară în DOOM. Păstrând proporțiile, în aceeași situație se află și varianta etimologică sandală, scoasă din $\mathrm{DOOM}^{2}$ în favoarea exclusivă a celei analogice sanda, soluție inversă comparativ cu cea adoptată în cazul dubletului similar caramelă/caramea, unde doar forma etimologică a avut câștig de cauză la nivel literar. Procedeul refacerii unei forme regulate mai scurte dintr-una de plural este frecvent întâlnit în română și merită luat în considerare, cu girul comunității lingvistice, dar, cel puțin în cazul neologismelor, forma anterioară nu merită să fie aruncată la coș sau socotită greșită. Admisibilitatea unor forme similare celor de mai sus nu denotă incultură, ci mai degrabă recunoașterea și asumarea unor tendințe firești de pronunțare a propriei limbi, validate de generațiile anterioare. 
Un alt aspect al acceptării libertății oferite de structura și de funcționarea limbii este cel al morfologiei. Alături de numeroasele dublete de plural ale numelor, mai ales ale neutrelor, cunoscute însă explicit și punctual mai degrabă de utilizatorii interesați sau curioși ai DOOM-ului (amalgame și amalgamuri, antete și anteturi, debușee și debușeuri, maratoane și maratonuri, slogane și sloganuri, tunele și tuneluri etc.), circulă în variaţie liberă multe altele similare, care nu sunt încă acceptate oficial, dar care au mare frecvență și motive măcar de toleranță, dacă nu de acceptabilitate: balsame și balsamuri, bazare și bazaruri, cadrane și cadranuri, caiace și caiacuri, intervale și intervaluri, jurnale și jurnaluri, spitale și spitaluri etc.; decoltee și decolteuri, expozee și expozeuri, ghişee și ghișeuri, ondulee și onduleuri, relee și releuri, turnee și turneuri etc.; bareme și baremuri, castele și casteluri, colete și coleturi, duete și dueturi, eclere și ecleruri etc; azile și aziluri, clavire și claviruri, parbrize și parbrizuri, profile și profiluri, turnire și turniruri etc. În majoritatea acestor cazuri, vorbitorii nativi, instruiți sau nu, aleg una sau alta dintre formele de plural puse la dispoziție de structura limbii proprii și o folosesc ca atare, fără ca prin asta să încalce regulile limbii, ci doar o opțiune convențională valabilă temporar. Deviații evidente de la normalitatea flexionară a limbii, cel puțin din acest punct de vedere, se explică fie printro necunoaștere din partea vorbitorului a celor mai elementare reguli, fie cu intenție ironică sau ludică. După părerea noastră, a cere unui nativ să știe, să recunoască și, eventual, să folosească exclusiv dubletele de neutru plural recomandate în DOOM este un apel nejustificat și păgubos exclusiv la memorie, valabil doar dacă tu, ca examinator, chiar asta urmărești: cât de bine și de mult ține minte un candidat seturi de cuvinte și forme considerate corecte. Observațiile de mai sus sunt valabile și în cazul flexiunii verbale cu sau fără sufix, din interiorul conjugărilor I și IV, unde oscilațiile se manifestă atât la cuvintele vechi, cât și, mai rar, la cele noi. Alături de dubletele recomandate din punct de vedere normativ, cităm diverse altele similare, a căror folosire alternantă nu trebuie în mod particular criticată la nivelul curent al exprimării: aclamă și aclamează, bântuie și bântuiește, bombăne și bombănește, clămpăne și clămpănește, dăinuie și dăinuiește, digeră și digerează, dilată și dilateazăa, disipă și disipează, evaporă și evaporează, extirpă și extirpează, ghemuie și ghemuiește, glăsuie și glăsuiește, hăcuie și hăcuiește, hărție și hărțiește, ignoră și ignorează, (iși închipuie și (ișși) închipuiește, înghesuie și înghesuiește, (se) înhaită și (se) înhăiteazăa învăluie și invăluiește, (se) lăfăie și (se) lăfăiește, mânuie și mânuiește, năzuie și năzuiește, răzuie și răzuiește, tăinuie și tăinuiește, trăncăne și trăncănește, troncăne și troncănește etc. 
Într-un asemenea context, rostul şi rolul educației este acela de a face să fie cunoscute mecanismele de funcționare a limbii cu respectarea structurilor ei esențiale și, în interiorul lor, de a permite vorbitorilor să aleagă firesc una sau alta dintre posibilitățile oferite de limbă pentru exprimarea unor idei, gânduri, mesaje etc. Pentru aceasta, ar trebui schimbată optica asupra propriei limbi, ca parte componentă a unei identități pe care ne-o asumăm fără să trebuiască să facem un caz din asta. Apartenența la un spațiu istoric, la o limbă, religie sau cultură nu trebuie clamată, ci simțită și trăită ca atare prin transmiterea unor valori celor pe care îi creștem și îi educăm, anume respectarea trecutului și învățarea din meritele și greșelile lui pentru a putea avea o istorie viitoare, primatul libertății de exprimare într-un mod decent, responsabil, echilibrat și adecvat, folosirea asumată a limbii și promovarea trăsăturilor ei către ceilalți în tot ceea ce are ea substanțial. Tinerii din epoca Centenarului trebuie să înțeleagă că limba pe care o folosesc ei astăzi nu este ceva fără rădăcini și, ca urmare, oricând dispensabil, ci că ea are în spate o istorie și o cultură, pe de o parte, deja milenare, manifestate latent și firesc și, pe de altă parte, construite prin voință expresă, experimente și exemplu personal, menite să ridice nivelul de civilizație și de trai al poporului din care facem parte și să ne integreze acolo unde ne bucurăm (sau ne iluzionăm ?) să fim astăzi... Mai trebuie să fie capabili, măcar în acest moment centenar, să discearnă între falsele modele "de succes" care vorbesc la televizor ca și cum ar fi pe stradă sau în propria ogradă din mahala (lasă că strada nu ar trebui să fie un spațiu al egocentrismului, al vulgarității și al prostului-gust) și modelele - e adevărat, mai puțin vizibile - din viața reală, care promovează libertatea de gândire exprimată în cuvinte alese, care se raportează la limbă ca la un bun de preț și care, prin exemplu implicit, îndeamnă la un comportament decent și la luarea în considerare a valorilor autentice. Ceea ce vorbim noi astăzi nu este nici pe departe o succesiune de inovații personale, ci reflectă experiența lingvistică a predecesorilor noștri, atât a celor simpli și necunoscuți, cât și a celor care și-au dorit și au „luptat”, mai mult sau mai puțin manifest, pentru ridicarea acestei limbi la rangul de limbă de cultură, capabilă să funcționeze astăzi în același fel cu principalele limbi de cultură și de civilizație europene, cu aceleași probleme şi cu aceleași tendințe. Română face parte dintre limbile oficiale ale Uniunii Europene, unde avem responsabilitatea să ne străduim să fim considerați egali alături de toți ceilalți, cu mentalități comune sau măcar asemănătoare, cu valori similare și cu sentimentul unității în diversitate. Elitele noastre intelectuale oscilează, pe bună dreptate, între tolerarea amuzată care ascunde, totuși, dezaprobarea, și respingerea categorică a abaterilor 
lingvistice, în funcție de gradul de incultură, de vulgaritate, de prostie și de vizibilitate a celor care le promovează în spațiul public. Deranjante și periculoase nu sunt apartenența dorită a cuiva la un grup socioprofesional și o anumită manifestare lingvistică în consecință, ci mai ales (auto)promovarea iluziei de reușită în viață prin indiferență față de ceilalți, prin lipsa de control în modul în care vorbește cineva și prin suficiența minimumului cultural pe care și-l arogă acel cineva.

Celor care sunt încă în măsură să învețe și care doresc să devină oameni integri și să fie apreciați pentru faptele și vorbele lor, în acest moment aniversar, le urez să se detașeze de „mareea neagră” a inculturii sesizabile, din păcate, într-o parte a mass-mediei noastre (criticată de Gh. Borțun, 2015), să creadă în creativitatea și expresivitatea limbii noastre, prezente atât la nivel lexical (Adriana Stoichițoiu-Ichim, 2001, 2006), cât și la cel frazeologic (Liviu Groza, 2005, 2017), să recunoască rolul major al latinei în devenirea și modernizarea limbii noastre (Theodor Hristea, 2003) și să se implice în cercetarea limbii cu umor, înțelegere și meticulozitate (Zafiu, 2001, Dumistrăcel, 2017). „Tendinţele actuale ale limbii române” de care vorbea Al. Graur în 1968 s-au recalibrat către economie şi eficiență, completate, în aparență paradoxal, de individualitate și expresivitate, în mod asemănător cu ceea ce se întâmplă în spațiul lingvistic european. Starea de astăzi a limbii române oglindește starea societății noastre din ultimele trei decenii, cu bunele și cu relele ei, însă construirea unei societăți care să-și folosească libertatea cu decență nu va fi nicicând posibilă fără educație lingvistică.

\section{BIBLIOGRAFIE DE REFERINȚĂ:}

\section{Dictionare:}

DEX 98 - Dicționarul explicativ al limbii române. Ediția a II-a (conducătorii lucrării: acad. Ion Coteanu, dr. Lucreția Mareş), Bucureşti, Editura Univers Enciclopedic, 1998.

DEXI 07 - Dicționarul explicativ ilustrat al limbii române. Coordonator: Eugenia Dima, Chișinău, Editura Arc - Gunivas 2007.

DLR = Dicționarul limbii române. Serie nouă. Redactori responsabili: acad. Iorgu Iordan, acad. Alexandru Graur şi acad. Ion Coteanu. Din anul 2000, redactori responsabili: acad. Marius Sala şi acad. Gheorghe Mihăilă. Bucureşti, Editura Academiei 1965-2005.

DOOM $^{1}=$ Dicționarul ortografic, ortoepic şi morfologic al limbii române, redactor responsabil: Mioara Avram, Bucureşti, Editura Academiei, 1982. 
$\mathrm{DOOM}^{2}=$ Dicționarul ortografic, ortoepic şi morfologic al limbii române, ediția a II-a revăzută şi adăugită, coordonator: Ioana Vintilă-Rădulescu, Bucureşti, Editura Univers Enciclopedic, 2005.

MDN 00 = Marele dicționar de neologisme, de Florin Marcu, București, Editura Saeculum, 2000.

NODEX 02 - Noul dicționar explicativ al limbii române, București, Editura Litera, 2002.

\section{Volume, studii:}

Borțun, Dumitru, Mareea neagră: limba română sub asediu. Greșeli de exprimare în massmedia din România, colecția Comunicare media, București, Editura Tritonic, 2015.

Coșeriu, Eugeniu, Lecții de lingvistică generală, Editura ARC, Chișinău, 2000.

Dumistrăcel, Stelian, Cuvintele, încotro? Lingvistică pentru toate televiziunile, Colecția „Media. Studii și eseuri”, Iași, Editura Polirom, 2017.

Graur Alexandru, Tendințele actuale ale limbii române, București, Editura Științifică, 1968.

Groza, Liviu, Dinamica unităților frazeologice în limba română actuală, București, Editura Universității din București, 2005.

Groza, Liviu, Creativitate și expresivitate în frazeologia limbii române, București, Editura Universității din București, 2017.

Hristea, Theodor, Latina și importanța ei pentru realizarea unei exprimări literare, în Pană Dindelegan, Gabriela (coord.), Aspecte ale dinamicii limbii române actuale (II), București, Editura Universității din București, p. 263-289, 2003.

Stoichițoiu-Ichim, Adriana, Vocabularul limbii române actuale. Dinamică, influențe, creativitate, București, Editura All, 2001.

Stoichițoiu-Ichim, Adriana, Creativitate lexicală în româna actuală, București, Editura Universității din București, 2006.

Zafiu, Rodica, Diversitate stilistică în româna actuală, București, Editura Universității din București, 2001.

\section{About Education, Liberty and Decency in Using and Cultivating the Language}

Abstract: This communication presents the linguistic education's major role in making a consistent and assumed profile for the romanian speaker, who has the liberty of choosing the best way to communicate in accordance with the context and who can promote a decent utterance based on knowing the rules and liberties of his own language.

Key-words: education, liberty, decency, knowledge and tolerance. 